Chinese Hegemony 



\section{Chinese Hegemony}

GRAND STRATEGY AND IN TERNATIONAL INSTITUTIONS IN EAST ASIAN HISTORY

\section{Feng Zhang}

Stanford University Press

Stanford, California 
Stanford University Press

Stanford, California

(C) 2015 by the Board of Trustees of the Leland Stanford Junior University. All rights reserved.

No part of this book may be reproduced or transmitted in any form or by any means, electronic or mechanical, including photocopying and recording, or in any information storage or retrieval system without the prior written permission of Stanford University Press.

Printed in the United States of America on acid-free, archival-quality paper

Library of Congress Cataloging-in-Publication Data

Zhang, Feng, 1980- author.

Chinese hegemony : grand strategy and international institutions in East Asian history / Feng Zhang.

pages $\mathrm{cm}$

Includes bibliographical references and index.

ISBN 978-0-8047-9389-6 (cloth : alk. paper)

I. China-Foreign relations-East Asia. 2. East Asia-Foreign relations-

China. 3. China-History-Ming dynasty, I368-I644. 4. Hegemony-ChinaHistory. 5. Hegemony-East Asia-History. I. Title.

DS740.6I.Z53 20I5

$327.5105-\mathrm{dc} 23$

2014041549

ISBN 978-0-8047-9504-3 (electronic)

Typeset by Newgen in II/I4 Garamond 
To my wife Shu Man, for all your love and sacrifice, and to our daughter, Zhang Han, for the faith we have in you 
